\title{
The Interleukins
}

\author{
WARREN STROBER AND STEPHEN P. JAMES
}

Mucosal Immunity Section, Laboratory of Clinical Investigation, National Institutes of Allergy and Infectious Diseases, National Institutes of Health, Bethesda, Maryland 20892

\begin{abstract}
In this review we have summarized the large mass of information that has accumulated in recent years relative to the heterogeneous group of molecules known as the interleukins (IL), the lymphokines, and the cytokines that control the growth and differentiation of cells of the hematopoietic and lymphoid lineage and cells of other lineages. Our intent is to provide the informed generalist with a body of information with which to interpret and understand forthcoming studies of this important class of molecules, particularly those with clinical import. (Pediatr Res 24:549-557, 1988)
\end{abstract}

The nomenclature governing IL has arisen haphazardly from the order of their discovery and other "trivial" considerations. Thus, the various designations frequently have little to do with the origin or the function of the individual molecules. An additional deficiency of the current nomenclature is that the IL do not include the various interferons and certain other factors that, for all intents and purposes, are also IL. On this basis, it is not unreasonable to expect that a new nomenclature will eventually be devised. In the present work, we have used the current nomenclature and have provided a more or less complete list of synonyms. As an additional frequently used convention, we sometimes refer to the IL as lymphokines when they are produced by lymphocytes and as cytokines when they are produced by nonlymphoid cells.

\section{IL-1}

IL-1 was first identified as a lymphokine by Gery and Waksman (1) who showed that macrophages produce a factor capable of augmenting $T$ cell responses to antigens and mitogens. This factor ultimately proved to have an extraordinary variety of functions and was in fact shown to be identical with several cytokines identified both before and after its discovery. Among the latter are endogenous pyrogen (a factor known to cause fever), leukocytic endogenous mediator (an inducer of acute phase reactants and neutrophilia) catabolin, osteoclast-activating factor and hemopoietin-1 (2-4). IL-1 is a phylogenetically old molecule that predates the evolution of lymphocytes and immunoglobulins; on this basis it is not surprising that its activities "transcend" immune function.

IL- 1 consists of not one but two very distinct molecules (IL$1 \alpha$ and IL- $1 \beta$ ) (Table 1 ) that are products of separate genes (both of which, in humans, are on chromosome 2) (5-8). The two IL1 are structurally quite dissimilar except for a region of homology which is likely to be the recognition site for the IL-1 receptor (9). This surprising difference may reflect the fact that the two forms

Received May 23, 1988; accepted July 12, 1988.

Correspondence to Warren Strober, M.D., Head, Mucosal Immunity Section, Laboratory of Clinical Investigation, National Institutes of Allergy and Infectious Diseases, Building 10, Room $11 \mathrm{~N} 250$, National Institutes of Health, Bethesda, MD 20892. of IL- 1 occupy separate biologic niches, IL- $1 \beta$ being the predominant secreted form and IL- $1 \alpha$ being the main membrane-bound form (10). In recent years, considerable evidence has accrued showing that the membrane-bound form of IL-1 is a biologically active molecule that can participate in the costimulation of $\mathrm{T}$ cells by antigen-pulsed macrophages.

IL-1 is produced by macrophages and a wide variety of other cells such as keratinocytes, astrocytes, and mesangial cells (11). In macrophages IL- 1 production is stimulated by a variety of agents such as lipopolysaccharide (LPS), phorbol esters, leukotrienes, immune complexes, UV irradiation, and agents that induce phagocytosis $(11,12)$. In addition, $T$ cells interacting with macrophages, either by cell-cell contact or via lymphokines, can induce IL-1 synthesis $(11,12)$. Agents that suppress IL-1 secretion include those which down-regulate immune responses generally such as cyclosporin A, corticosteroids, and prostaglandins (1315 ); in addition, because IL-1 is itself a stimulator of corticosteroid and prostaglandin synthesis, IL-1 may have negative feedback effects on IL-1 production. Finally, naturally occurring but as yet incompletely characterized IL-1 inhibitors have been identified in febrile patients and pregnant women; the existence of such inhibitors indicate that negative feedback of IL- 1 synthesis may normally occur in vivo (16).

IL-1 activity is mediated by widely distributed IL-1 receptors. Recent work suggests that the latter occur as high affinity and low affinity receptors and that both IL- $\alpha$ and IL- $\beta$ bind to the same receptor $(17,18)$. IL-1 binding to its receptor on T cells is an activation signal accompanied by an increase in protein kinase $\mathrm{C}$ activity and increase in cytosolic calcium concentration (12). However, this is not the case with neutrophils, a fact that may explain the lack of IL-1 effects on neutrophil chemotaxis and oxidative metabolism. Finally, the binding of IL-1 to its receptor leads to internalization of the receptor-ligand complex and downregulation of receptor expression; such internalized IL-1 is not degraded and may be transported into the nucleus where it can conceivably exert control on intranuclear processes $(18,19)$.

The diverse activities of IL- 1 reflect both direct effects of this interleukin as well as indirect effects brought about by mediators released secondary to IL-1 secretion. One way of organizing and analyzing these activities is based on the unifying view that IL-1 is the IL most responsible for the inflammatory changes regularly induced by pathogenic organisms or autoimmune processes (1, 12). Thus, in the CNS, IL-1 acts on the hypothalamic thermoregulatory center and other CNS centers to cause fever and sleep and acts in many areas of the CNS to increase secretion of various neuropeptides (including endorphins), corticotropin-releasing factor, and $\mathrm{ACTH}$; the latter, in combination with direct effects of IL-1 on the adrenal gland, leads to increased circulating steroid levels and thus the many inflammatory changes brought about by steroids. Similarly, IL- 1 acts as an inflammatory mediator in the liver, where it increases synthesis of acute phase reactants and metallothionines and decreases synthesis of albumin. In addition, in this organ it inhibits lipoprotein lipase synthesis and thus causes decreased lipid utilization and lactic acidosis. 
Table 1. IL

\begin{tabular}{|c|c|c|c|c|}
\hline Factor & Form & Synonyms & Major sources & Major effects \\
\hline IL-1 & $\alpha$ & Endogenous pyrogen & $\begin{array}{l}\text { Macrophages; also: } \\
\text { endothelial epithelial, } \\
\text { fibroblast, and other } \\
\text { cell types } \\
\text { Membrane bound form } \\
\text { of IL-1 on macro- } \\
\text { phages }\end{array}$ & $\begin{array}{l}\text { Proliferation and differentiation } \\
\text { of } \mathrm{T} \text { and } \mathrm{B} \text { cells and other } \\
\text { cell types. Fever, tissue catab- } \\
\text { olism, chemotaxis } \\
\text { Lymphocyte activation and dif- } \\
\text { ferentiation }\end{array}$ \\
\hline IL-2 & & $\begin{array}{l}\mathrm{T} \text { cell derived growth } \\
\text { factor } \\
\mathrm{T} \text { cell replacing factor } \\
\text { Killer helper factor }\end{array}$ & Activated $\mathrm{T}$ cells & $\begin{array}{l}\text { Cofactor for growth and differ- } \\
\text { entiation of } \mathrm{T} \text { cells and } \mathrm{B} \\
\text { cells. Increased cytotoxic ac- } \\
\text { tivity of } \mathrm{T} \text { and NK cells and } \\
\text { monocytes. }\end{array}$ \\
\hline IL-3 & & $\begin{array}{l}\text { Multi-CSF (human) } \\
\text { Mast cell growth fac- } \\
\text { tor (mouse) } \\
\text { Burst promoting ac- } \\
\text { tivity } \\
\text { Erythroid CSF } \\
\text { Eosinophil CSF }\end{array}$ & Activated T cells & $\begin{array}{l}\text { Stimulates growth of multipo- } \\
\text { tential stem cells and eryth- } \\
\text { roid and myeloid progeni- } \\
\text { tors. In mouse supports mast } \\
\text { cell growth. }\end{array}$ \\
\hline IL-4 & & $\begin{array}{l}\text { BCGF } \\
\text { BSF-1 }\end{array}$ & $\mathrm{T}$ cells & $\begin{array}{l}\text { Growth factor for: B cells and } \\
\text { some T cells, erythroid, mye- } \\
\text { loid, and megakaryocytic } \\
\text { precursors, increases HLA } \\
\text { Class II expression, Increases } \\
\text { IgG1, IgE (mouse). }\end{array}$ \\
\hline IL-5 & & $\begin{array}{l}\text { BCGF-II } \\
\text { IgA-enhancing factor } \\
\text { Eosinophil CSF }\end{array}$ & Activated T cells & $\begin{array}{l}\text { Induces differentiation of eosin- } \\
\text { ophils, augments prolifera- } \\
\text { tion of activated B cells (in } \\
\text { mouse), enhances IgA pro- } \\
\text { duction }\end{array}$ \\
\hline IL-6 & & $\begin{array}{l}\text { IFN- } \beta \\
\text { BCDF } \\
\text { BSF-2 } \\
\text { Hepatocyte-stimulat- } \\
\quad \text { ing factor }\end{array}$ & $\begin{array}{l}\text { Fibroblasts, macro- } \\
\text { phages } \\
\text { Minor: } \mathrm{T} \text { cell lines }\end{array}$ & $\begin{array}{l}\text { B cell differentiation } \\
\text { Hepatocytes: acute phase reac- } \\
\text { tants } \\
\text { Weak anti-viral effects }\end{array}$ \\
\hline TNF & $\alpha$ & $\begin{array}{l}\text { TNF } \\
\text { Cachectin }\end{array}$ & $\begin{array}{l}\text { LPS stimulated } \\
\text { Macrophages }\end{array}$ & $\begin{array}{l}\text { Necrosis of tumors } \\
\text { Wasting of chronic disease } \\
\text { Pyrogenic } \\
\text { Endotoxic shock } \\
\text { Bone resorption }\end{array}$ \\
\hline & $\beta$ & Lymphotoxin & Lymphocytes & Same as $\alpha$ \\
\hline
\end{tabular}

Other less organ-specific inflammatory effects of IL-1 include its capacity to augment connective tissue cell growth and collagen formation, to increase bone resorption (osteoclast activity) and to induce prostaglandin synthesis. In addition, IL-1 augments the catabolic effects of tumor necrosis factor (TNF) and is synergistic with the latter in the generation of hypertension and the capillary leak syndrome. Finally, IL-1 has notable inflammatory effects on the vascular system where it acts to deliver inflammatory cells to sites of tissue injury and to contain invasive pathologic processes. These effects include the enhancement of endothelial cell proliferation, the release of potent vasodilators, and the initiation of clot formation.

Interfacing with these "general" activities of IL-1 are the effects of this interleukin on hematopoietic and lymphoid cells. First, IL-1 stimulates the synthesis of colony-stimulating factors and/ or acts as a colony-stimulating factor itself (hemopoietin-1 activity) $(20,21)$. Thus, IL-1 is an important component of the bone marrow responses to inflammatory influence. Second, IL-1 plays a key role as a second messenger in antigen/mitogen-induced activation of $T$ cells: it acts in combination with the latter stimuli to cause maximal expression of IL-2 receptors and the production of IL-2 $(11,22)$. This central activity of IL-1 is actually its defining feature as an IL (see Fig. 1) and establishes the molecule as one whose effects are primary to many other lymphokine effects (at least as far as the T cell is concerned) (Fig. 1). Third, IL-1 has important effects on other (non-T) lymphoid cells and on macrophages. In this context, it acts on activated B cells (usually in association with other lymphokines) to induce cell proliferation and differentiation $(23,24)$ and on macrophages to causes synthesis of prostaglandins and cytokines and to bring about increased macrophage cytotoxic activity $(25,26)$.

These various properties of IL-1 obviously help the organism to eliminate exogenous noxious agents or injurious processes of an endogenous origin. It is important to note, however, that 


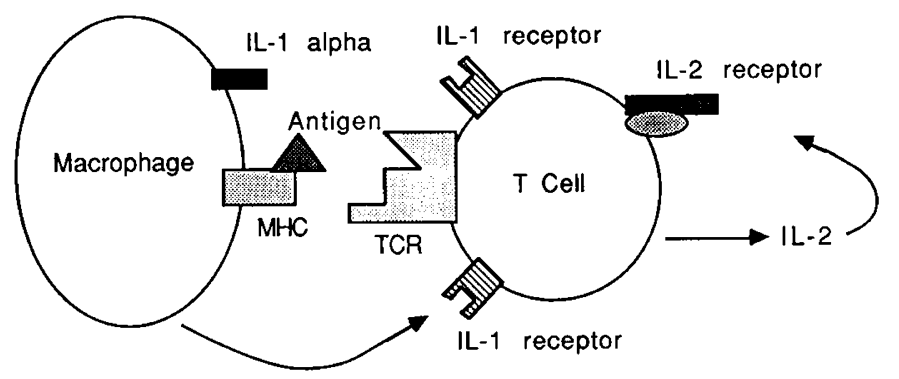

IL-1 Beta

Fig. 1. IL-1 (either as membrane-bound IL- $1 \alpha$ or soluble IL-1 $\beta$ ) is a costimulant of the $T$ cell during Ag-driven stimulation of the $T$ cell via the $T$ cell receptor $(T C R)$. Such co-stimulation results in IL-2 production and IL-2 receptor expression and further $\mathrm{T}$ cell proliferation. $M H C$, major histocompatability complex.

under certain circumstances these very same properties allow IL1 to become a mediator of tissue injury. This is seen most clearly in studies of the pathogenesis of arthritis, wherein it has been shown that IL-1 can induce arthritis when injected into a normal joint and can enhance arthritis produced by other stimuli when given systemically (27). These pathologic effects of IL-1 may be due to the fact that, as alluded to above, IL-1 can act as a chemotactic factor, cause the release of prostaglandins and collagenase, induce osteoclasis, and bring about degranulation of leukocytes and the release of proteolytic enzymes and other destructive substances. Based on what is known about IL-1 in arthritis one might postulate that many autoimmune diseases are facilitated, if not caused by IL-1-mediated effects. On this basis it becomes reasonable to postulate that an IL-1 antagonist, perhaps one structurally related to one of the aforementioned natural IL-1 inhibitors, would serve as a mode of therapy for immunologically mediated tissue injury.

At present there are no clearly documented diseases caused by primary IL-1 deficiency or overproduction. However, given the potent and ubiquitous effects of this very central IL either of these kinds of defects may well be lethal at a very early stage and thus escape detection by current methods.

\section{IL-2}

The existence of mitogenic substances acting on lymphocytes or $T$ cell lines has been known for over $20 \mathrm{yr}$, but it was not until Morgan et al. (28) and Gillis and Smith (29) showed that a factor was necessary for normal $T$ cell proliferation that the identification and characterization of the factor that became known as IL-2 began in earnest. In humans IL-2 is a $15.4-\mathrm{kDa}$ glycosylated protein encoded by a gene on the long arm of chromosome $4(30)$. It acts on activated $T$ cells and (to a lesser extent) B cells, as well as with natural killer cells and thymocytes, causing these cells to proliferate and/or manifest differentiated cell function (e.g. cytotoxicity) $(30,31)$.

$\mathrm{T}$ cells display both a high affinity and a low affinity IL-2 receptor. The high affinity receptor is a heterodimer which is composed of a p55 moiety (known as the Tac antigen) which binds IL-2 with low affinity and a p75 moiety which binds IL-2 with intermediate affinity $(32,33)$. Activated lymphocytes express both high affinity (p75/p55) and low affinity (p55) receptors, whereas large granular lymphocytes (including NK cells) express receptors of intermediate affinity (p75) (33). IL-2 receptors are also found on $\mathrm{B}$ cells and various cells of the macrophage/ monocyte lineage. Of interest, IL-2 receptor expression on HTLV-1-virus infected $T$ cells is increased by 5 - to 10 -fold over that of mitogen-activated $T$ cells. This may be due to the fact that the virus produces a protein (a product of the viral tat gene) which acts on an IL-2 receptor gene promoter to increase IL-2 receptor transcription (34). It is reasonable to suppose that the tat gene product may be a homologue of a normal intracellular protein involved in IL-2 receptor expression.

IL-2 is synthesized by both T cells (CD4 cells > CD8 cells) and large granular lymphocytes (31). A variety of stimuli induce IL-2 synthesis including specific antigens, antibodies reacting with cell surface molecules important in activation pathways (CD3 and CD2 antigens), and nonspecific activating substances such as phorbol esters and mitogens. As mentioned earlier, IL-1 is necessary for maximal antigen- or mitogen-induced T cell IL2 synthesis and may even be necessary for IL-2 synthesis to occur at all. The uncertainty relating to this issue is due to the fact that $T$ cell stimulation requires some form of cell presentation of antigen or mitogen bound to cells which contain IL-1 in their membranes; thus, stimulation of $\mathrm{T}$ cells occurring in the absence of fluid-phase IL-1, may actually be due to membrane-bound IL-1. This being said, T cell activation and IL-2 production can be brought about in the absence of IL-1 by various chemical stimuli (e.g. phorbol esters and ionomycin). As for inhibition of IL-2 synthesis, this is brought about by a variety of immunosuppressive substances such as glucocorticoids, cyclosporin A, and prostaglandins (31).

Defects in IL-2 production or IL-2 receptor expression have been noted in a number of disease states, but in no instance has it been shown that such abnormalities are a primary feature of the disease. Among the diseases with IL-2 production abnormalities are acquired immunodeficiency (AIDS), autoimmune disease such as type 1 diabetes mellitus, systemic lupus erythematosus, and hypogammaglobulinemia (35-37). In the latter disease, the IL-2 deficiency may be responsible for the defective (lymphokine-activated killer) activity associated with the disease. However, IL-2 receptor expression defects have been seen in immunodeficiency states, multiple sclerosis, and adult $\mathrm{T}$ cell leukemia $(38,39)$.

At the moment the most important relationship of IL-2 to disease involves its use in the therapy of tumors. The basis of such therapy is that IL-2 can activate a form of natural killer cell (known as the lymphokine-activated killer cell or LAK cell) that is cytotoxic to various tumor cells (40). In preliminary studies in which high doses of IL-2 were administered with LAK cells activated in vitro, objective antitumor responses were obtained in about $20 \%$ of patients, including those with melanomas, renal cell carcinoma, and chemotherapy-resistant lymphomas (41). However, this therapy is associated with severe toxicity and requires a high degree of clinical support. Additional studies are now underway using other regimens, including those in which intermediate doses of IL- 2 are administered by constant infusion or for prolonged periods with LAK cells. In addition, expansion of tumor-specific cytotoxic cells using IL-2 both in vitro and in vivo is being explored. Finally, it is possible that IL-2 administration will potentiate other antitumor therapies such as those using cytotoxic drugs and other IL.

Aside from its potential role as a antitumor agent, IL-2 may have a role as a therapeutic agent in infection, autoimmunity, and immunodeficiency. In this regard, it has been shown that IL-2 can augment specific antibody responses which are low because of specific Ir gene abnormalities and, as mentioned above, IL-2 can cause increased antigen-nonspecific cytotoxic function necessary for the destruction of potential pathogens (42).

\section{IL-3 AND OTHER COLONY STIMULATING FACTORS (CSF)}

IL-3 is representative of a family of cytokines involved in the growth and differentiation of hematopoietic and lymphoid precursor cells. This family consists of a group of molecules known as the CSF and includes the lymphokines or cytokines that share the capacity to stimulate granulocyte and/or macrophage colony formation in bone marrow cultures $(43,44)$. Members of this family so far identified include: 1) M-CSF (CSF-1), a heavily glycosylated 47 - to $76-\mathrm{kDa}$ glycoprotein that stimulates the 
growth of macrophage colonies and monocytic cell lines (45). This cytokine is a disulfide-linked dimer encoded by a single gene that gives rise to related forms of the molecule as a result of alternative RNA processing (46-50). Recent evidence suggests the existence of both membrane-bound and soluble forms (49). 2) GM-CSF (CSF- $\alpha$ ), a 14- to $35-\mathrm{kDa}$ glycoprotein produced by various cells including fibroblasts, endothelial cells, and activated $T$ cells that has growth-enhancing effects on granulocyte/macrophage/eosinophil colonies $(43,44,51)$, and in combination with erythropoietin, on erythroid and multipotential colonies $(52,53)$. In addition, GM-CSF has effects on mature cells in that it causes neutrophil and eosinophil activation (54) and induces neutrophil phagocytosis (52). This cytokine is encoded by a gene on chromosome 5 (and is deleted in the 5q- syndrome) (55). 3) G-CSF, a 19 - to $20-\mathrm{kDa}$ glycoprotein produced by macrophages and/or endothelial cells that stimulates mainly granulocytes, but may have indirect effects on other precursors particularly when it is present in high concentration (56-58). As is the case of MCSF, G-CSF is encoded by a single gene which may produce different forms of the molecule as a result of differential RNA splicing $(59,60)$. 4) Multi-CSF (IL-3) (also known as burstpromoting activity, mast cell growth factor, and $\mathrm{P}$ cell-stimulating activity), a 20 - to $25-\mathrm{kDa}$ glycoprotein that is derived from activated $\mathrm{T}$ cells and that supports the growth of virtually all types of hematopoietic progenitor cells, usually at several stages of their development (usually in concert with other CSF) (43, $44,61,62$ ). This CSF is encoded by a gene on chromosome 5 . 5) Erythropoietin, a $34-$ to $39-\mathrm{kDa}$ glycoprotein produced in the kidney that predominantly stimulates erythroid precursor cells but also has effects on other precursors in association with other CSF $(63,64)$. It is produced by a gene on chromosome $7(65)$.

The activity of multi-CSF (IL-3) on mast cell development is of special interest. In recent years, it has become clear that mast cells are separable into two types (at least in rodents), connective tissue mast cells (or typical mast cell), and mucosal mast cells (or atypical mast cell) which differ in proteoglycan, mediator, and proteolytic enzyme content (66). The development of these two mast cell types appears to be under the control of separate cytokines, the connective tissue mast cell being influenced by a fibroblast-derived factor and the mucosal mast cell being dependent on IL-3 (67). Thus, during parasitic infection accompanied by mast cell infiltration, $T$ cells that secrete IL-3 play an essential host-defence role.

The CSF have distinct receptors distributed on undifferentiated and mature cells of various lineages $(43,44)$. However, since multi-CSF competes with the other CSF and GM-CSF competes with G-CSF and M-CSF, it is apparent that CSF with activity on multiple cell types bind to a number of cell lineage specific receptors (68). Of great theoretical interest is the recent demonstration that the M-CSF receptor and the oncogene product, C-fms, are identical (69). This finding links oncogene products to growth factors. To date, CSF production has been found in fibroblasts, endothelial cells, lymphocytes, and macrophages and may yet be found in other cell types as well (Fig. 2). IL-1 and TNF appear to be inducing factors for CSF production and thus monocytes, the chief source of IL-1/TNF, may play a key role in CSF production (70).

The therapeutic applications of CSF administration are currently being explored. GM-CSF administration to monkeys induces striking increases in leukocytes of most types (including erythrocytes) (71). Similar results relative to neutrophils have been obtained with G-CSF (72). On the basis of these data, GMCSF and G-CSF may be useful in certain disease states, such as those after ablative chemotherapy for bone marrow transplantation and in infections associated with neutropenia. In addition, efforts are underway to study the effect of erythropoietin in the treatment of anemia associated with uremia (73). Finally, inasmuch as CSF may control leukemic cell growth and development, it is possible that these cytokines may play a role in the treatment of myeloid and lymphoid dyscrasias.

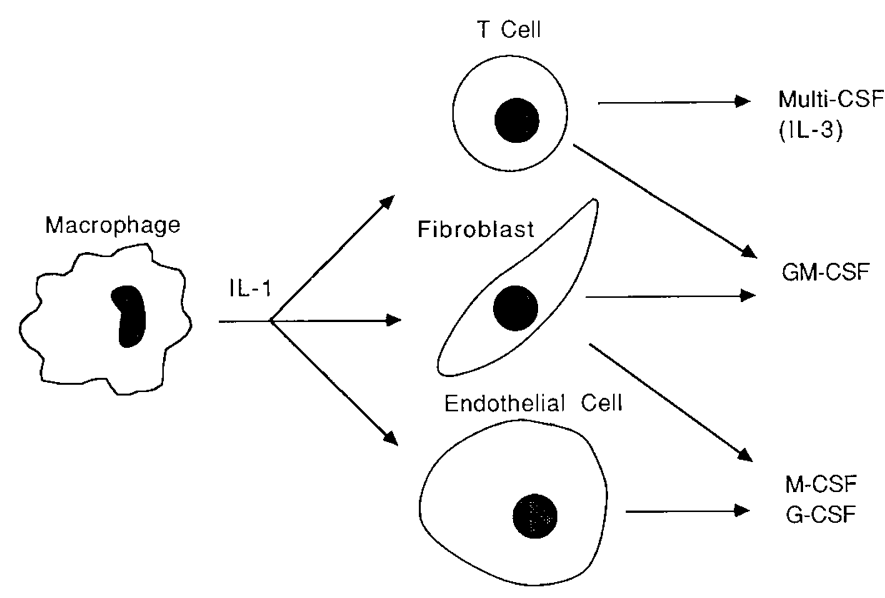

Fig. 2. CSF are produced by several cells. As shown here IL-2 can induce CSF production by these cells.

\section{IL-4 (BCGF-I, BSF-1)}

In 1982 Howard et al. (74) discovered that resting normal mouse $\mathrm{B}$ cells which were costimulated with anti- $\mu$ antibody could proliferate in the presence of a factor present in the supernatant of activated T cells (phorbol ester-treated-EL-4 thymoma cells) (74). This factor was distinct from IL-2 and was initially named $\mathrm{B}$ cell growth factor (BCGF-1 or BSF-1). However, with the recognition that BCGF-1 is one of several cytokines that act on $\mathrm{B}$ cells and that BCGF-1 also acts on $\mathrm{T}$ cells in addition to $\mathrm{B}$ cells, this factor was ultimately given the designation, IL-4 $(74,75)$. In humans, the IL-4 gene encodes a protein of 153 amino acids, including a putative 24-amino acid signal peptide (76); thus, the deduced relative mol. wt. of the secreted protein is approximately $15 \mathrm{kDa}$, not including the additional mass due to posttranslational glycosylation. Human IL-4 has approximately $50 \%$ sequence homology with murine Il-4.

IL-4 can act on resting B cells, even before exposure to a primary stimulus: B cells preexposed to IL-4 undergo enhanced proliferation when later exposed to LPS (77). This finding corresponds to the fact that IL-4 receptors are found on the cell membrane during the $G_{0}$ phase of the cell cycle, in contrast to IL-2 receptors that are not found on the cell membrane until the cell is in the $G_{1}$ phase (78). This is not to say that IL-4 effects are limited to unactivated $B$ cells, inasmuch as it has been shown that IL-4 also augment proliferation of activated B cells (79). Other effects of IL-4 on B cells include the induction of class II major histocompatibility complex expression (80), the expression of CD23 (low affinity IgE receptor) (81) and the up-regulation of the IL-4 receptor itself (77); these effects allow the B cell to respond to other stimulatory lymphokines and to interact with other cells.

Recently it has been shown that IL-4 plays an important role in isotype differentiation of the murine B cell: B cells stimulated with LPS in the presence of IL-4 preferentially express IgG1 (rather than $\operatorname{IgG3})$ and $\operatorname{IgE}(82,83)$. If this effect on isotype expression operates at the level of the isotype switching mechanism or at the level of selection of preswitched cells is not entirely clear; however, the former possibility is favored by the fact that IgG1 expression can be observed in clonal B cell populations. A related observation is that IL-4 induction of IgG1 expression is inhibited by interferon- $\gamma($ IFN- $\gamma$ ) and the latter itself promotes IgG2a expression (84). It is thus apparent that not only IL-4, but other lymphokines, have important effects on B cell isotype differentiation (Fig. 3). The above studies clearly establish IL-4 as a major B cell lymphokine in the mouse. It is not yet certain if human IL-4 will have similar activities on human B cells. However, data are emerging that IL-4 can selectively increase IgE synthesis by human peripheral blood B cells; on the other 


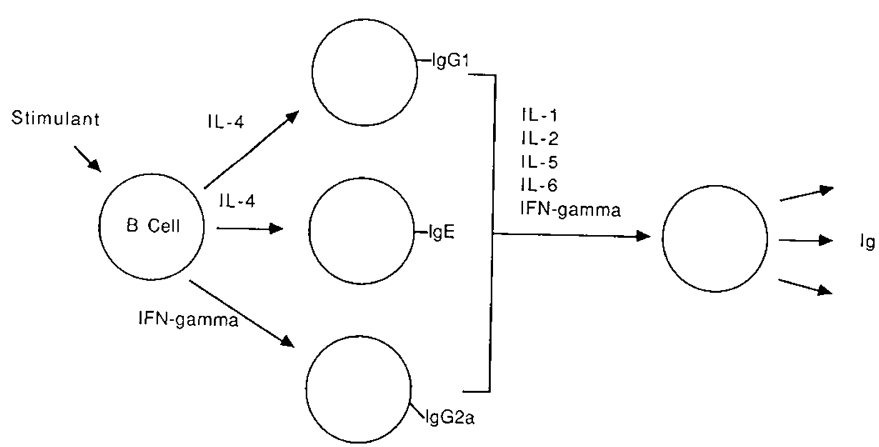

Fig. 3. IL-4 (and IFN- $\gamma$ ) play an important role in isotype differentiation. IL-4 leads to IgG1 production probably by directing the switch IgM B cells to IgG1 B cells. A similar mechanism may govern IL-4 enhancement of IgE B cells and IFN- $\gamma$ enhancement of IgG2a B cells. As shown, a variety of factors contributes to terminal B cell differentiation.

hand, there is some evidence that IL-4 down-regulates human peripheral blood $\mathrm{B}$ cell responses to certain mitogens.

As alluded to above, IL-4 acts as a proliferation factor for cells other than B cells (85). Thus, IL-4 enhances T cell proliferation and causes resting $T$ cells to undergo enhanced proliferation when exposed to other costimuli such as phorbol myristate acetate. In addition, IL-4 acts to support proliferation and expansion of immature erythroid, myelomonocytic, and megakaryocytic precursors as well as macrophages and mast cells (in the mouse). These observations suggest that IL- 4 is a broadly reactive growth and differentiation factor that is not limited in its effects on any one cell type.

Recently, Mosmann et al. (86) have shown that the production of IL-4 and other lymphokines may be a property of certain T cell subclasses. In particular, these authors found that murine $\mathrm{T}$ cell clones can be classified into two groups: those producing IL2 and IFN- $\gamma$, so-called $\mathrm{TH}_{1}$ cells, and those producing IL- 4 and IL-5, so-called $\mathrm{TH}_{2}$ cells. The different $\mathrm{T}$ cell clones thus identified in vitro may represent different functional classes of $T$ cells that arise as a result of different forms of immunologic stimulation. Thus, viral infection may induce $\mathrm{TH}_{1}$ cells and thereby evoke the production of complement-fixing IgG2a antibodies, whereas parasitic infection may induce $\mathrm{TH}_{2}$ cells and thus lead to the production of IgE antibodies and mediator release. Evidence that this is actually the case comes from studies showing that in vivo administration of anti-IL-4 monoclonal antibody inhibits IgE production in Nippostrongylus brasiliensis-infected animals (87) and conversely, in vivo anti-IgD administration, a method of inducing B cell activation and production of IL-4 by $\mathrm{T}$ cells, is associated with increased $\mathrm{IgGl}$ and $\mathrm{IgE}$ production (84).

At the moment disorders of IL-4 production have not been described, although it is possible that they will be found in diseases characterized by abnormal B cell function, such as immunodeficiency states or autoimmune diseases. If indeed IL4 proves to be a key factor necessary for IgE production, then it may be possible to modify allergic states by antagonists of IL-4 activity.

\section{IL-5}

IL-5 was initially identified as a factor present in supernatants of $T$ cell cultures which was capable of causing B cells to either differentiate into cells actively producing antibody or to undergo proliferation; for this reason IL-5 was initially called $\mathrm{T}$ cell replacing factor or BCGF-II $(88,89)$. Further work established that IL-5 is both biochemically and functionally different from IL-4: the mol. wt. of the two lymphokines differ and IL-5 acts on cells only after initial activation, whereas IL-4 acts on resting cells (90-93). The latter fact suggests that the IL-5 receptors are not present on resting cells as is the case for IL-4. It has not yet been determined if induction of proliferation and differentiation by IL- 5 involve the same cellular mechanisms; however, these effects may sometimes be dissociated because the differentiative effects of IL-5 can occur in the absence of proliferation (94).

IL-5 has a molecular mass of $50-60 \mathrm{kDa}$ and is a multimer of disulfide linked, functionally-active $18-\mathrm{kDa}$ subunits (95). Cloning studies predict that the IL-5 gene encodes for a $12.8-\mathrm{kDa}$ polypeptide core in humans, and that the actual $18-\mathrm{kDa}$ molecular mass is due to glycosylation (96). Regarding the latter, there is one study in which it is suggested that IL-5 binds to its receptor via a lectin-like interaction involving in $\mathrm{N}$-acetylgalactosamine (97).

The IL-5 receptor is as yet poorly characterized. However, as alluded to above, there is considerable evidence that its appearance on the cell surface is cell-cycle dependent and that it recognizes carbohydrate moieties on the IL-5 molecule. In addition, data have been reported that show that the gene encoding the IL-5 receptor is X-linked (98). This suggests that IL-5controlled processes can underlie certain X-linked disorders.

Recently it has been shown that IL-5 has isotype-specific effects: after LPS activation of B cells in the presence of IL-5, IgA but not IgG subclass production is increased (99). However, such isotype specificity may be more apparent than real, because LPS alone stimulates maximal IgG subclass synthesis, so that the apparent class-specific effect of IL-5 may simply be a result of the inability of LPS alone to cause maximal IgA responses. This view is supported by the fact that in antigen-driven systems IL5 does augment IgM and IgG responses (88). Even if IL-5 effects are not isotype-specific, it may be of particular importance to IgA B cell differentiation since IgA B cells appear to be unresponsive to certain stimuli, such as LPS.

IL-5 effects, in common with those of IL-4, are not restricted to $\mathrm{B}$ cells. In this regard, it has been shown that IL-5 has colonystimulating activity for eosinophils in liquid bone marrow culture (100) and that IL-5 augments T cell cytotoxic capacity (101). The latter may relate to the fact that IL-5 induces IL- 2 receptor expression.

As yet IL-5 has not been implicated in human disease. However, in view of its strong B cell proliferative and differentiative functions, IL-5 should be considered in the pathogenesis of the immunodeficiencies, particularly those marked by B cell dysfunction. This possibility obtains added weight from the aforementioned fact that genes involved in certain B cell immunodeficiencies and that encoding the IL-5 receptor may be Xlinked.

\section{IL-6 (BCDF, BSF-2, IFN- $\beta 2$, HEPATOCYTE-STIMULATING FACTOR)}

In recent years it has been shown that immunoglobulin secretion by the transformed B cell line CESS (102), by leukemic B cells (103), or by normal B cells stimulated with Staphylococcus aureus, Cowan I (104) could be costimulated by a soluble factor, termed $\mathrm{B}$ cell differentiation factor (BCDF or BSF-2) isolated from $\mathrm{T}$ cell lines or $\mathrm{T}$ cell hybridomas. The gene encoding this factor was ultimately cloned and sequenced (105) and the factor was designated IL-6; at this point, however, it became apparent that the factor was identical to IFN- $\beta 2$, a substance whose gene had been cloned at essentially the same time (106).

IL-6 is a $26-\mathrm{kDa}$ protein that has sequence and gene structure homology with G-CSF (106). The gene encoding this IL has several initiation sites that may be preferentially used in different tissues and that give rise to somewhat different forms of the molecule. Gene transcription of IL- 6 is enhanced by IL-1, and to a lesser extent by other cytokines such as TNF, platelet-derived growth factor, and IFN- $\beta 1$; in addition, LPS increases IL-6 mRNA synthesis in fibroblasts.

Unlike the other type I IFN genes (IFN- $\alpha$ and IFN- $\beta 1$ genes) which are located on chromosome 9, the human IL-6 (IFN- $\beta 2$ ) 
gene is located on chromosome 7 (107). In addition, the IL-6 gene has only a $20 \%$ homology with other type 1 IFN and differs from the latter in containing large introns. These differences notwithstanding, IL- 6 mediates its effects via the same receptor as other type 1 IFN and shares with the latter certain properties such as the ability to inhibit virus replication, to induce specific IFN-activated genes and to have antimitogenic effects on fibroblasts (108). Thus, the weight of evidence suggests that IL-6 is in fact an IFN, but one that has evolved significantly from the other IFN (108).

IL-6 has been shown to be a terminal differentiation factor that causes B cells to differentiate into plasma cells in the absence of proliferation. This is illustrated by the fact that IL- 6 is essential for pokeweed mitogen (PWM)-induced $\mathrm{Ig}$ synthesis and that anti-IL-6 inhibits PWM-induced Ig production. Although IL-6 does not augment normal B cell proliferation, it has growthenhancing effects on activated B cells (i.e. B cell lines). Thus, IL6 effects on cells may depend somewhat on the preexisting state of cell activation.

In addition to its antiviral and B cell effects, IL-6 also has important up-regulatory effects on the synthesis of acute phase reactants by the hepatocyte. In this regard, IL-6 is identical to monocyte-derived hepatocyte-stimulation factor (109). The very diverse activities of IL- 6 as well as the fact that IL- 6 is produced by a variety of cell types indicate that IL- 6 plays a central role during inflammation along with IL-1 and IFN- $\gamma$. Indeed, there is emerging evidence that many of the inflammatory activities usually ascribed to IL-1 may in reality be due to IL-6 (110-112).

\section{TNF: TNF- $\alpha$ (CACHECTIN) AND TNF- $\beta$ (LYMPHOTOXIN,} LT)

In 1975 Carswell et al. (113) showed that the serum of BCGprimed, endotoxin-treated animals contains a macrophage-derived factor, called TNF, which was capable of causing hemorrhagic necrosis of tumors. Subsequently human TNF was purified to homogeneity (114) and based on the partial amino acid sequence of the purified material, a cDNA clone of TNF was obtained from which the full amino acid sequence was ultimately derived (115). Independently of these TNF studies, other investigators studied the mechanisms of cachexia associated with chronic inflammation (116). These studies led to the identification of a macrophage-derived factor that suppressed lipoprotein lipase synthesis (117) and that, when ultimately purified and sequenced, was found to be identical to TNF (118-120).

In yet other studies factors were isolated from activated lymphocytes which are able to lyse target cells $(121,122)$. Once the cDNA clone of one such factor, termed LT was identified and expressed $(123,124)$, it was found that the amino acid sequences of LT and TNF share $26 \%$ identity and $51 \%$ homology when conservative substitutions are made. In addition, natural and recombinant human LT share with TNF the ability to lyse tumor targets. On the basis of this structural and functional similarity, a new nomenclature was proposed: TNF- $\alpha$ for the macrophage factor and TNF- $\beta$ for the lymphocyte factor.

Recombinant human TNF- $\alpha$ has a mol. wt. of approximately $17 \mathrm{kDa}$ and consists of 157 amino acids whereas recombinant human TNF- $\beta$ has a mol. wt. of $25 \mathrm{kDa}$ and consists of 171 amino acids (125). Both TNF genes are located on human chromosome 6 near the major histocompatibility locus and in close proximity to one another; thus, it is likely that they have arisen from a common ancestral gene through tandem duplication (126).

In vivo administration of endotoxin to rabbits causes a rapid rise in TNF- $\alpha$ in plasma, followed by rapid clearance. The latter is thought to be caused by TNF- $\alpha$ membrane receptor-bearing cells present in the liver, skin, kidneys, lung, and gastrointestinal tract (127). It is now thought that many of the effects of administration of bacterial products and LPS are mediated directly by production of TNF- $\alpha$ (126). In addition, there is considerable evidence that TNF- $\alpha$ is the central mediator of the wasting that accompanies chronic disease (126). LPS is a potent inducer of TNF synthesis by macrophages, and large doses of TNF- $\alpha$ mimic the effects of endotoxic shock, suggesting that this protein is the major mediator of the deleterious effects of endotoxin.

TNF- $\alpha$ shares with IL- 1 the capacity to act as a potent endogenous pyrogen; this is caused both by a direct effect on the hypothalamus and an indirect augmenting effect on IL-1 production. Other IL-1-like effects of TNF- $\alpha$ include the induction of prostaglandin $E_{2}$ and collagenase synthesis by human synovial cells and dermal fibroblasts (128) and TNF- $\alpha$-mediated bone resorption. In regard to the latter, the production of TNF- $\alpha$ by malignant $B$ cells in multiple myeloma may be important to the bone lesions encountered in this disease (129). However, TNF- $\beta$ has been shown to have a growth factor-like effect on human $B$ cells and fibroblasts $(130,131)$.

The activities of both TNF- $\alpha$ and TNF- $\beta$ may be due to their capacity to augment synthesis of other cytokines. In addition to the effect of TNF on IL-1 synthesis already mentioned, the TNF cause production of GM-CSF (132) and IFN- $\beta 2$. In turn, other cytokines may act by causing TNF production, because it has been shown that IFN- $\gamma$ and LPS can cause increased TNF production (133). Finally, the antitumor effects of TNF are enhanced by INF- $\gamma(134)$.

Given their production by activated macrophages and lymphocytes, it seems likely that the TNF play an important physiologic role in the pathogenesis of human inflammatory diseases. As discussed above, they are no doubt important elements in the acute effects of endotoxin as well as in the wasting diathesis of chronic disease. Thus, antagonists of TNF may be useful in the therapy of endotoxic shock and chronic inflammatory disease. Also of possible therapeutic significance is the antineoplastic effect of TNF; however, this will only be feasible if the toxic effects of this IL can be separated from the antineoplastic effects. At this time there are no known human diseases characterized by deficiency of TNF production.

\section{SUMMARY}

As the reader of this review can readily appreciate, the IL have an almost bewildering array of functions that involve not only the lymphoid and hematopoietic systems, but also many nonmarrow-derived cellular systems. The future of IL research lies in the further delineation of IL effects on cell-cell interactions and on the dissection of IL effects on intracellular processes. In addition, with the advent of recombinant IL the way is now clear to the widespread evaluation of IL or IL agonists and antagonists in a myriad of clinical studies.

\section{REFERENCES}

1. Gery I, Waksman B 1972 Potentiation of the T lymphocyte response to mitogens. II. The cellular source of potentiating mediator(s). J Exp Med 136:143-155

2. Atkins E 1960 The pathogenesis of fever. Physiol Rev 40:580-646

3. Merriman CR, Pulliam LA, Kampschmidt RF 1977 Comparison of leukocytic pyrogen and leukocytic endogenous mediator. Proc Soc Exp Biol Med 154:224-227

4. Saklatvala J, Sarsfield SJ, Townsend Y 1985 Pig interleukin-1. Purification of two immunologically different leukocyte proteins that cause cartilage resorption, lymphocyte activation, and fever. J Exp Med 162:1208-1222

5. Lomedico PT, Gubler U, Hellman CP, Dukovich M, Giri JG, Pan YE, Collier K, Semionow R, Chua AO, Mizel SB 1984 Cloning and expression of murine interleukin-1 in Escherichia coli. Nature 312:458-462

6. Auron PE, Webb AC, Rosenwasser LJ, Mucci SF, Rich A, Wolff SM Dinarello CA 1984 Nucleotide sequence of human monocyte interleukin-1 precursor cDNA. Proc Natl Acad Sci USA 81:7907-7911

7. Clark BD, Collins KL, Gandy MS, Webb AC, Auron PE 1986 Genomic sequence for prointerleukin-1-beta: possible evolution from a reverse transcribed prointerleukin-1 alpha gene. Nucleic Acids Res 14:7897-7914

8. Auron PE, Rosenwasser LJ, Matsushima K, Copeland T, Dinarillo CA Oppenheim JJ, Webb AC 1985 Human and murine interleukin 1 passes sequences and structural similarities. J Mol Cell Immunol 2:169-177

9. March CJ, Mosley B, Larsen A, Cerretti P, Braedt G, Price V, Gillis S, Henny CS, Kronheim SR, Grabstein K, Conlon PJ, Hopp TP, Cosman D 1985 
Cloning sequence and expression of two distinct human interleukin-1 complementary DNAs. Nature 315:641-646

10. Conlon PJ, Grabstein KH, Alpert A, Prickett KS, Hopp TP, Gillis S 1987 Localization of human mononuclear cell interleukin-1. J Immunol 139:98102

11. Durum SK, Schmidt JA, Oppenheim JJ 1985 IL-1: An immunological prospective. Annu Rev Immunol 3:263-287

12. Dinarello CA 1988 Biology of interleukin-1. FASEB J 2:108-115

13. Bunjes D, Hardt C, Rollinghoff M, Wagner H 1981 Cyclosporin A mediates immunosuppression of primary cytotoxic $T$ cell responses by impairing the release of interleukin-1 and interleukin-2. Eur J Immunol 11:657-661

14. Snyder DS, Unanue ER 1982 Corticosteroids inhibit murine macrophage Ia expression and interleukin 1 production. J Immunol 129:1803-1805

15. Vane J, Botting R 1987 Inflammation and the mechanisms of action of antiinflammatory drugs. FASEB J I:89-96

16. Brown K, Muchmore AV, Rosenstreich DL 1987 Uromodulin, an immunosuppressive protein derived from pregnancy urine, is an inhibitor of interleukin 1. Proc Natl Acad Sci USA 83:9119-9123

17. Kilian PL, Kaffka KL, Stern AS, Woehle D, Benjamin WR, DeChiara TM, Gubler U, Farrar JJ, Mizel SB, Lomedico PT 1986 Interleukin 1- $\alpha$ and interleukin $1-\beta$ bind to the same receptor on T cells. J Immunol 136:45094514

18. Lowenthal JW, MacDonald HR 1985 Binding and internalization of interleukin- 1 by $\mathrm{T}$ cells. Direct evidence for high- and low-affinity classes of inter leukin-1 receptor. J Exp Med 164:1060-1074

19. Mizel SB, Kilian PL, Lewis JC, Paganelli KA, Chizzonite RA 1987 The interleukin 1 receptor. Dynamics of interleukin 1 binding and internalization of T cells and fibroblasts. J Immunol 138:2906-2912

20. Sieff CA, Tsai S, Faller DV 1987 Interleukin 1 induces cultured human endothelial cell production of granulocyte-macrophage colony-stimulating factor. J Clin Invest 79:48-51

21. Stanley ER, Bartocci A, Patinkin D, Rosendall M, Bradley TR 1986 Regulation of very primitive multipotent, hematopoietic cells by hemopoietin-1. Cell 45:667-674

22. Smith KA, Lachman LB, Oppenheim JJ, Favata MF 1980 The functional relationship of the interleukins. J Exp Med 151:1551-1556

23. Howard M, Paul WE 1983 Regulation of B cell growth and differentiation by soluble factors. Annu Rev Immunol 1:307-333

24. Leibson JH, Marrack P, Kappler J 1982 B cell helper factor. II. Synergy among three helper factors in the response of $\Upsilon$ cells and macrophagedepleted B cells. J Immunol 139:1398-1402

25. Dinarello CA, Marnoy SO, Rosenwasser LJ 1983 Role of arachidonate metabolism in the immunoregulatory function of human leukocytic pyrogen/lymphocyte-activating factor/interleukin 1. J Immunol 130:890-895

26. Billiau AJ, Van Domme J, Opdenakker G, Fibbe WE, Falkenburg JHF, Content J 1986 Interleukin 1 as cytokine inducer. Immunobiology 172:323335

27. Mizel SB, Dayer JM, Krane SM, Mergenhagen SE 1981 Stimulation of rheumatoid synovial cell collagenase and prostaglandin production by partially purified lymphocyte-activing factor (interleukin 1). Proc Natl Acad Sci USA 78:2474-2477

28. Morgan DA, Ruscetti FW, Gallo RC 1976 Selective in vitro growth of $\Upsilon$ lymphocytes from normal human bone marrow. Science 193:1007-1008

29. Gillis S, Smith KA 1977 Long term cutlure of tumour-specific cytotoxic T cels. Nature 268:154-156

30. Malkovsky M, Sondel PM 1987 Interleukin 2 and its receptor: structure, function and therapeutic potential. Blood Rev $1: 1-12$

31. Watson J, Mochizuki 1980 Interleukin 2: a class of T cell growth factors. Immunol Rev 51:257-278

32. Robb RJ, Green WC, Rusk CM 1984 Low and high affinity cellular receptors for interleukin 2: implications for the level of Tac antigen. J Exp Med 160:1126-1146

33. Waldmann TA 1986 The structure, function and expression of interleukin 2 receptors on normal and malignant lymphocytes. Science 232:727-732

34. Greene WC, Leonard WJ, Wano Y, Svetlik PB, Peffer NJ, Sodroski JG, Rosen CA, Goh WC, Haseltine WA 1986 Trans-activator gene of HTLV-Il induces IL-2 receptor and IL-2 cellular gene expression. Science 232:877880

35. Borzy MA 1987 Interleukin 2 production and responsiveness in individuals with acquired immunodeficiency syndrome and the generalized lymphadenopathy syndrome. Cell Immunol 104:142-153

36. Linker-Israeli M, Bakke AC, Kitridou RC, Gendler S, Gillis S, Horwitz DA 1983 Defective production of interleukin 1 and interleukin 2 in patients with systemic lupus erythematosus (SLE). J Immunol 130:2651-2655

37. Gao L, Malkovsky M, Webster ADB, Asherson GL 1985 Impaired lymphokine-activated killer-cell activity in patients with hypogammaglobulinemia. Lancet 2:340 (abstr)

38. Depper JM, Leonard WJ, Kronke M, Waldmann TA, Greene WC 1984 Augmented $\mathrm{T}$ cell growth factor receptor expression in HTLV-I infected human leukemic T cells. J Immunol 133:1691-1695

39. DeFreitas EC, Sandberg-Wollheim M, Schonely K, Boufal M, Koprowski H 1986 Regulation of interleukin 2 receptors on $T$ cells from multiple sclerosis patients. Proc Natl Acad Sci USA 83:2637-2641

40. Grimm EA, Mazumder A, Zhang HZ, Rosenberg SA 1982 The lymphokine activated killer cell phenomenon: lysis of NK resistant fresh solid tumor cells by IL-2 activated autologous human peripheral blood lymphocytes. J Exp Med 155:1823-1841
41. Lotze MT, Chang AE, Seipp CA, Simpson C, Vetto JT, Rosenberg SA 1986 High-dose recombinant IL-2 in the treatment of patients with disseminated cancer. Responses, treatment related morbidity and histologic findings. JAMA 256:3117-3124

42. Kawamura H, Rosenberg SA, Berzofsky JA 1985 Immunization with antigen and interleukin 2 in vivo overcomes Ir gene low responsiveness. J Exp Med $162: 381-386$

43. Nicola NA, Vadas M 1984 Hematopoietic colony-stimulating factors. Immunol Today 5:76-80

44. Sieff C 1987 Hematopoietic growth factors. J Clin Invest 79:1549-1557

45. Byrne PV, Guilbert LJ, Stanley ER 1981 Distribution of cells bearing receptors for a colony-stimulating factor (CSF-1) in murine tissues. J Cell Biol 91:848853

46. Stanley ER, Heard PM 1977 Factors regulating macrophage production and growth. Purification and some properties of the colony stimulating factor from medium conditioned by mouse L cells. J Biol Chem 252:4305-4312

47. Das SK, Stanley ER, Guilbert LJ, Forman LW 1981 Human colony-stimulating factor (CSF-1) radioimmunoassay: resolution of three subclasses of human colony-stimulating factors. Blood 58:630-64

48. Das SK, Stanley ER 1982 Structure-function studies of a colony stimulating factor (CSF-1). J Biol Chem 257:13679-13684

49. Kawasuki ES, Ladner MB, Wang AM, Van Arsdell J, Warren MK, Cogne MY, Schweickart VL, Lee MT, Wilson KJ, Boosman A, Stanley ER, Ralph P, Mark DF 1985 Molecular cloning of a complementary DNA encoding human macrophage-specific colony-stimulating. Science 230:291-296

50. Wong GG, Witek JS, Temple PA, Wilkens KM, Leary AC, Luxenberg DP, Jones SS, Brown EL, Kay RM, Orr EC, Shoemaker C, Golde DW, Kaufman RJ, Hewisk RM, Wang EA, Clark SC 1985 Human GM-CSF: molecular cloning of the complementary DNA and purification of the natural and recombinant proteins. Science 228:810-815

51. Nicola NA, Burgess AW, Metcalf D 1979 Similar molecular properties of granulocyte-macrophage colony-stimulating factors produced by different mouse organs in vitro and in vivo. J Biol Chem 254:5290-5299

52. Metcalf D, Begley CG, Johnson GR, Nicola NA, Vadas MA, Lopex AF, Williamson DG, Wong GG, Clark SC, Wang EA 1986 Biologic properties in vitro of a recombinant human granulocyte-macrophage colony-stimulating factor. Blood 67:37-45

53. Sieff CA, Emerson SG, Donahue RE, Nathan DG, Wang EA, Wong GG, Clark SC 1985 Human recombinant granulocyte-macrophage colony-stimulating factor: a multilineage hematopoietin. Science 230:1171-1173

54. Vadas MA, Varigos G, Nicola N, Pincus S, Dessein A, Metcalf D, Battye FL 1983 Eosinophil activation by colony-stimulating factor in man: metabolic effects and analysis by flow cytometry. Blood 61:1232-1241

55. Huebner K, Isobe M, Croce CM, Golde DW, Kaufman SE, Gasson JC 1985 The human gene encoding GM-CSF is at 5q21-q32, the chromosome region deleted in the 5q-anomaly. Science 230:1282-1285

56. Strife A, Lambek C, Wisniewski D, Gulati S, Gasson J, Golde D, Welte K, Gabrilove J, Clarson B 1987 Activities of four purified growth factors on highly enriched human hematopoietic progenitor cells. Blood 69:1508-1523

57. Metcalf D, Nicola NA 1983 Proliferative effects of purified granulocyte colony-stimulating factor (G-CSF) on normal mouse hematopoietic cells. J Cell Physiol 116:198-206

58. Welte K, Platzer E, Lu L, Gabrilove JL, Levi E, Mertelsmann R, Moore MAS 1985 Purification and biochemical characterization of human pluripotent hematopoietic colony-stimulating factor. Proc Natl Acad Sci USA 82:15261530

59. Souza LM, Boone C, Gabrilove J, Lai PH, Zsabo KM, Murdock DC, Chazin VR, Bruszewski J, Lu H, Chen KK, Barendt J, Platzer E, Moore MAS, Mertelsmann R, Welte K 1986 Recombinant human granulocyte colonystimulating factor: effects on normal and leukemic myeloid cells. Science 232:61-65

60. Nagata S, Tsuchiya M, Asano S, Yamamoto O, Hirata Y, Kubota N, Oheda M, Homura H, Yamazaki T 1986 The chromosomal gene structure and two mRNAs for human granulocyte colony-stimulating factor. EMBO J 5:575581

61. Clark-Lewis I, Shrader JW 1981 P cell-stimulating factor: biochemical characterization of a new T cell-derived factor. J Immunol 127:1941-1947

62. Bazill GW, Haynes M, Garland J, Dexter TM 1983 Characterization and partial purification of a haemopoietic cell growth factor in WEHI-3 cell conditional medium. Biochem J 210:747-759

63. SieffCA, Emerson SG, Mufson A, Gesner TG, Nathan DG 1986 Dependence of highly enriched human bone marrow progenitors on hematopoietic growth factors and their response to recombinant erythropoietin. J Clin Invest 77:74-81

64. Eaves AC, Eaves CJ 1984 Erythropoiesis in culture. Clin Haematol 13:371391

65. Law ML, Cai G-Y, Lin F-K, Wei A, Huang S-Z, Hartz J-H, Morse H, Lin C-H, Jones C, Kao F-T 1986 Chromosomal assignment of the human erythropoietin gene and its DNA polymorphism. Proc Natl Acad Sci USA 83:6920-6924

66. Barrett KE, Metcalfe D 1984 Mast cell heterogeneity: evidence and implications. J Clin Immunol 4:253-261

67. Guy-Grand D, Dy M, Luffau G, Vassalli P 1984 Gut mucosal mast cells origin, traffic and differentiation. J Exp Med 160:12-28

68. Walker F, Nicola NA, Metcalf D, Burgess AW 1985 Hierarchical downmodulation of hemopoietic growth factor receptor. Cell 43:269-276

69. Sherr CJ, Rettenmier CW, Sacca R, Roussel MF, Look AT, Stanley ER 1985 
The c-fms proto-oncogene product is related to the receptor for the mononuclear phagocyte growth factor, CSF-1. Cell 41:665-676

70. Sieff CA, Niemeyer C, Tsai S, Clark SC, Faller DV Monocytes regulate hematopoiesis by stimulating the production of hematopoietic growth factor by mesenchymal cells. 1986 Blood 68(suppl 1):180a(abstr 597)

71. Donahue RE, Wang EA, Stone S, Kamen R, Wong GS, Sehgal DG, Nathan DG, Clark SC 1986 Stimulation of haematopoiesis in primates by continuous infusion of recombinant human GM-CSF. Nature 321:872-875

72. Welte K, Bonilla MA, Gillia AP, Boone T, Potter GK, Gabrilove J, Moore MAS, O'Reilly RJ, Souza L 1987 Recombinant human granulocyte colonystimlating factor. Effects on hematopoiesis in normal and cyclophosphamidetreated primates. J Exp Med 165:941-948

73. Gillio AP, Bonilla MA, O'Reilly RJ, Potter GK, Bonne T, Souza L, Welte K Effect of recombinant human G-CSF on hematopoietic reconstitution following autologous bone marrow transplantation in primates. 1986 Blood 68(suppl 1):283a(abstr 1009)

74. Howard M, Farrar J, Hilfiker M, Johnson B, Takatsu K, Hamaoka T, Paul WE 1982 Identification of a T cell-derived B cell growth factor distinct from interleukin 2. J Exp Med 155:914-923

75. Homa Y, Sideras T, Naito T, Bergstedt-Lindqvist S, Azuma C, Severinson E, Tanabe T, Kinashi T, Matsuda F, Yaoita Y, Honjo T 1986 Cloning of cDNA encoding the murine IgG1 induction factor by a novel strategy using SP6 promoter. Nature 319:640-646

76. Yokota T, Otsuka T, Mosmann T, Banchereau J, DeFrance T, Blanchard D, De Vries JE, Lee F, Arai K-I 1986 Isolation and characterization of a human interleukin cDNA clone, homologous to mouse B-cell stimulatory factor 1 , that expresses B-cell and T-cell-stimulating activities. Proc Natl Acad Sci USA 83:5894-5898

77. Paul WE, Ohara J 1987 B cell stimulatory factor-1/interleukin-4. Annu Rev Immunol 5:429-459

78. Ohara J, Paul WE 1987 High affinity receptors for B cell stimulatory factor1 (interleukin-4) expressed on lymphocytes and other cells of hematopoietic lineage. Nature 325:537-540

79. Rabin RM, Mond JJ, Ohara J, Paul WE 1986 B cell stimulatory factor (BSF)1 prepares resting $B$ cells to enter $S$ phase in response to anti-IgM and to lipopolysaccharide. J Exp Med 164:517-531

80. Noelle R, Krammer PH, Ohara J, Uhr JW, Vitetta ES 1984 Increased expression of Ia antigens on resting B cells: an additional role for B-cell growth factor. Proc Natl Acad Sci USA 81:6149-6153

81. DeFranco T, Aubry JP, Rousset F, Vandervliet B, Bonnefoy JY, Arai N, Takebe Y, Yokota T, Lee F, Arai K, DeVries J, Banchereau J 1984 Human recombinant interleukin-4 induces Fc $\epsilon$ receptors (CD23) on normal human B lymphocytes. J Exp Med 165:1459-1467

82. Vitetta ES, Ohara J, Myers C, Layton J, Krammer PH, Paul WE 1985 Serological, biochemical, and functional identity of B cell-stimulatory factor 1 and B cell differentiation factor for IgG1. J Exp Med 162:1726-1731

83. Coffman RL, Ohara J, Bond MW, Carty J, Zlotnick E, Paul WE 1986 B cell stimulatory factor-1 enhances the IgE response of lipopolysaccharide-activated $B$ cells. J Immunol 136:4538-4541

84. Finkelman FD, Katona IM, Mosmann TR, Coffman RL 1988 IFN- $\gamma$ regulates the isotypes of Ig secreted during in vivo humoral immune responses. $J$ Immunol 140:1022-1027

85. Paul WE 1987 Interleukin 4/B cell stimulatory factor 1: one lymphokine, many functions. FASEB J 1:456-461

86. Mosmann TR, Cherwinski H, Bond MW, Giedlin MA, Coffman RL 1987 Two types of murine helper T cell clones. I. Definition according to profiles of lymphokine activities and secreted proteins. J Immunol 136:2348-2357

87. Finkelman FD, Katona I, Urban JF Jr, Snapper CM, Ohara J, Paul WE 1986 Suppression of in vivo polyclonal IgE responses by monoclonal antibody to the lymphokine BSF-1. Proc Natl Acad Sci USA 83:9675-9678

88. Takatsu K, Tominaga A, Hamaoka T 1980 Antigen-induced T cell-replacing factor (TRF). I. Functional characterization of a TRF-producing helper T cell subset and genetic studies on TRF production. J Immunol 124:2414 2422

89. Swain SL, Dennert G, Warner JF, Dutton RW 1981 Culture supernatants of a stimulated $\mathrm{T}$-cell line have helper activity that acts synergistically with interleukin-2 in the response of B cells to antigen. Proc Natl Acad Sci USA 78:2517-2521

90. Takatsu K, Harada N, Hara Y, Takahama Y, Yamada Y, Dobashi K, Hamaoka T 1985 Purification and physicochemical characterization of murine T cell replacing factor (TRF). $J$ Immunol 134:382-389

91. Swain SL 1985 Role of BCGF II in the differentiation to antibody secretion of normal and tumor B cells. J Immunol 134:3934-3943

92. O'Garra A, Warren DJ, Holman M, Popham AM, Sanderson CJ, Klaus GGB 1986 Interleukin 4 (B-cell growth factor II/eosinophil differentiation factor) is a mitogen and differentiation factor for preactivated murine B lymphocytes. Proc Natl Acad Sci USA 83:5228-5232

93. Swain SL, Howard M, Kappler J, Marrack P, Watson J, Booth R, Wetzel G, Dutton RW 1983 Evidence for two distinct classes of murine B cell growth factors with activities in different functional assays. J Exp Med 158:822-835

94. Harriman GR, Kunimoto DY, Elliot JF, Paetkau V, Strober W 1988 The role of IL-5 in IgA B cell differentiation. J Immunol 140:3033-3039

95. Kinashi T, Harada N, Severinson E, Tanabe T, Sideras P, Konishi M, Azuma T, Tominaga A, Bergstedt-Lindquist S, Takahashi M, Matsuda T, Yaoita Y, Takatsu K, Honjo T 1986 Cloning of complementary DNA encoding T cell replacing factor and identity with B cell growth factor II. Nature 324:70-73

96. Azuma T, Tanabe T, Konishi M, Kinashi T, Noma T, Matsuda F, Yaoita Y,
Takatsu K, Hammarstrom L, Edvard Smith CI, Severinson E, Honjo T 1986 Cloning of cDNA for human $T$ cell replacing factor (interleukin 5) and comparison with the murine homologue. Nucleic Acids Res 14:9149-9158

97. Takahama Y, Ono S, Hara Y, Hayashi S-I, Dobashi K, Hamaoka T 1985 Role of N-acetyl-D-galactosamine residue on B151K12-derived T cell-replacing factor (B151-TRF) molecule in B cell-receptor binding and -stimulating activity. $\mathrm{J}$ Immunol 135:2534-2540

98. Tominanga A, Takatsu K, Hamaoka T 1980 Antigen-induced T cell-replacing factor (TRF). II. X-linked gene control for the expression of TRF-acceptor site(s) on B lymphocytes and the preparation of specific antiserum to that receptor. J Immunol 124:2423-2429

99. Coffman RL, Shrader B, Carty J, Mosmann TR, Bone MW 1987 A mouse $\mathrm{T}$ cell product that preferentially enhances IgA production. I. Biologic characterization. J Immunol 139:3685-3690

100. Sanderson CJ, O'Garra A, Warren DJ, Klaus GGB 1986 Eospinophil differentiation factor also has B cell growth factor activity: proposed name interleukin 4. Proc Natl Acad Sci USA 83:437-440

101. Takatsu K, Kikuchi Y, Takahashi T, Honjo T, Matsumoto M, Harada N, Yamaguchi N, Tominaga A 1987 Interleukin 5, a T cell-derived B cell differentiation factor also induces cytotoxic T lymphocytes. Proc Natl Acad Sci USA 84:4234-4238

102. Muraguchi A, Kishimoto T, Miki Y, Kuritani T, Kaieda T, Yoshizaki K, Yamamura Y $1981 \mathrm{~T}$ cell-replacing factor-(TRF) induced IgG secretion in a human B blastoid cell line and demonstration of acceptors for TRF. J Immunol 127:412-416

103. Yoshizaki K, Nakagawa T, Kaieda T, Muraguchi A, Yamamura Y, Kishimoto T 1982 Induction of proliferation and Ig production in human B leukemic cells by anti-immunoglobulins and T cell factors. J Immunol 128:1296-1301

104. Okada M, Sakaguchi N, Yoshimura N, Hara H, Shimizu K, Yoshida N, Yoshizaki K, Kishoimoto S, Yamamura Y, Kishimoto T 1983 B cell growth factors and $\mathrm{B}$ cell differentiation factor from human $\mathrm{T}$ hybridomas. Two distinct kinds of $\mathrm{B}$ cell growth factor and their synergism in B cell proliferation. J Exp Med 157:583-590

105. Hirano $T$, Yasukawa $K$, Harada $H$, Taga $T$, Watanabe $Y$, Matsuda $T$, Kashiwamura S, Nakajima K, Koyama K, Iwamatsu A, Tsunasawa S, Sakiyama F, Matsui H, Takahara Y, Taniguchi T, Kishimoto T 1986 Complementary DNA for a novel human interleukin (BSF-2) that induces B lymphocytes to produce immunoglobulin. Nature 324:73-76

106. Sehgal PB, May LT 1987 Human $\beta 2$-interferon. J Interferon Res 7:521-527

107. Sehgal PB, Zilberstein A, Ruggieri M, May LT, Ferguson-Smith A, Slate DL, Revel M, Ruddle FH 1986 Human chromosome 7 carries the $\beta 2$-interferon gene. Proc Natl Acad Sci USA 83:5219-5222

108. Revel M, Zilberstein A 1987 Interferon- $\beta 2$ living up to its name. Nature 325:581-582

109. Gauldie J, Richards C, Harnish D, Lansdorp P, Baumann H 1987 Interferon $\beta 2 / B$ cell stimulatory factor type 2 shares identity with monocyte-derived hepatocyte stimulating factor and regulates the major acute phase protein response in liver cells. Proc Natl Acad Sci USA 84:7251-7255

110. Content J, De Wit L, Poupart P, Opdenakker G, Van Damme J, Billiau A 1985 Induction of a $26-\mathrm{kDa}$ protein mRNA in human cells treated with interleukin-1 related, leukocyte derived factor. Eur J Biochem 152:253-257

11. Kohase M, May LT, Tamm I, Vilcek J, Sehgal PB 1987 A cytokine network in human diploid fibroblasts: interactions of $\beta$-interferons, tumor necrosis factor, platelet-derived factor and interleukin-1. Mol Cell Biol 7:273-280

112. Helfgott DC, May LT, Sthoeger Z, Tamm I, Sehgal PB 1987 Bacterial lipopolysaccharide (endotoxin) enhances expression and secretion of $\beta 2$ interferon by human fibroblasts. J Exp Med 616:1300-1309

113. Carswell EA, Old LJ, Kassel RL, Green S, Fiore N, Williamson B 1985 An endotoxin-induced serum factor that causes necrosis of tumors. Proc Natl Acad Sci USA 72:3666-3670

114. Aggarwal BB, Kohr WJ, Hass PE, Moffat B, Spencer SA, Henzel WJ, Bringman TS, Nedwin GE, Goeddel DV, Harkins RN 1985 Human tumor necrosis factor. Production, purification, and characterization. J Biol Chem $260: 2345-2354$

115. Pennica D, Nedwin GE, Hayflick Seeburg PH, Derynck R, Palladino MA, Kohr WJ, Aggarwal BB, Goeddel DV 1984 Human tumour necrosis factor: precursor structure, expression and homology to lymphotoxin. Nature 312:724-729

116. Rouzer CA, Cerami A 1980 Hypertriglyceridemia associated with Trypanosoma brucei brucei infection in rabbits: role of defective triglyceride removal. Mol Biochem Parasitol 2:31-38

117. Kawakami M, Cerami A 1981 Studies of endotoxin-induced decrease in lipoprotein lipase activity. J Exp Med 154:631-639

118. Fransen L, Muller R, Marmenout A, Tavernier J, Van der Heyden J, Kawashima E, Chollet A, Tizard R, Van Heuverswyn H, Van Vliet A, Ruysschaert M-R, Fiers W 1985 Molecular cloning of mouse tumor necrosis factor CDNA and its eukaryotic expression. Nucleic Acids Res 13:4417-4429

119. Pennica D, Hayflick JS, Bringman TS, Palladino MA, Goeddel DV 1985 Cloning and expression in Escherichia coli of the cDNA for murine tumor necrosis factor. Proc Natl Acad Sci USA 82:6060-6064

120. Caput D, Beutler B, Hartogk, Brown-Shimer S, Cerami A 1986 Identification of a common nucleotide sequence in the $3^{\prime}$-untranslated region of mRNA molecules specifying inflammatory mediators. Proc Natl Acad Sci USA 83:1670-1674

121. Ruddle NH, Waksman BH 1968 Cytotoxicity mediated by soluble antigen and lymphocytes in delayed hypersensitivity. 3. Analysis of mechanism. $\mathbf{J}$ Exp Med 128:1267-1279 
122. Granger GA, Williams TW 1968 Lymphocyte cytotoxicity in vitro. Nature 218:1253-1254

123. Gray PW, Aggarwal BB, Benton CV, Bringman TS, Henzel WJ, Jarrett JA, Leung DW, Moffat B, Ng P, Svedersky LP, Palladino MA, Nedwin GE 1984 Cloning and expression of cDNA for human lymphotoxin, a lymphokine with tumor necrosis activity. Nature 312:721-724

124. Aggarwal BB, Henzel WJ, Moffat B, Kohr WJ, Harkins RN 1984 Primary structure of human lymphotoxin derived from 1788 lymphoblastoid cell line. J Biol Chem 260:2334-2344

125. Shalaby MR, Pennica D, Palladino MA Jr 1986 An overview of the history and biologic properties of tumor necrosis factors. Springer Semin Immunopathol 9:33-37

126. Beutler B, Cerami A 1986 Cachectin and tumour necrosis factor as two sides of the same biological coin. Nature 320:584-588

127. Beutler B, Milsark IW, Cerami A 1985 Cachectin/tumor necrosis factor: production, distribution, and metabolic fate in vivo. J Immunol 135:39723977.

128. Dayer J-M, Beutler B, Cerami A 1985 Cachectin/tumor necrosis factor stimulates collagenase and PGE2 production by human synovial cells and dermal fibroblasts. J Exp Med 162:2163-2168

129. Garrett IR, Durie BG, Nedwin GE, Gillespie A, Bringman T, Sabatini M,
Bertolini DR, Mundy GR 1987 Production of lymphotoxin, a bone-resorbing cytokine, by cultured human myeloma cells. N Engl J Med 317:526-532

130. Kehrl JH, Alvarez-Mon M, Delsing GA, Fauci AS 1987 Lymphotoxin is an important T cell-derived growth factor for human B cells. Science 238:1 1441146

131. Hofsli E, Austgulen R, Nissen-Meyer J 1987 Lymphotoxin-induced growth stimulation of diploid human fibroblasts in the presence and absence of gamma interferon. Scand J Immunol 26:585-588

132. Degliantoni G, Murphy M, Kobayashi M, Francis MK, Perussia B, Trinchieri G 1985 Natural killer (NK) cell-derived hematopoietic colony-inhibiting activity and NK cytotoxic factor. Relationship with tumor necrosis factor and synergism with immune interferon. J Exp Med 162:1512-1530

133. Nedwin GE, Svedersky LP, Bringman TS, Palladino MA Jr, Goeddel DV 1985 Effect of interleukin 2, interferon-gamma, and mitogens on the production of tumor necrosis factors alpha and beta. J Immunol 135:24922497

134. Esparza I, Mannel D, Ruppel A, Falk W, Krammer PH 1987 Interferon gamma and lymphotoxin or tumor necrosis factor act synergistically to induce macrophage killing of tumor cells and schistosomula of Schistosoma mansoni. J Exp Med 166:589-594

\section{Announcements}

\section{Abstract Deadline}

The American Pediatric Society and the Society for Pediatric Research announce the abstract deadline for the 1989 annual meeting (May 1-5, 1989, Washington Sheraton Hotel, Washington, D.C.) has been set as January 3, 1989.

For further information contact:

SPR-Ms. Debbie Wogenrich; 2650 Yale Blvd., S.E., Suite 104; Albuquerque, NM 87106; (505)764-9099.

APS-Dr. Audrey K. Brown, Department of Pediatrics, SUNY, Health Science Center at Brooklyn, 450 Clarkson Avenue, Box 49, Brooklyn, NY 11203; (718)270-1692.

\section{International Symposium on Pediatric Rheumatology Paris, July 21-22, 1989}

The main topics of this symposium will be: New insights in the physiopathogeny of inflammatory and autoimmune disorders (cytokines, genetics ...); Synovitis: Characteristics and functions of cells infiltrating the inflammatory joint; General disorders with joint manifestations in childhood; Therapeutics. General and local treatments, surgery ...

Abstracts forms will be available in November 1988. This meeting is organized for the week preceding the International Congress of Pediatrics held in Paris (July 23-28).

For information contact: Docteur Anne-Marie Prieur, Hôpital Necker-Enfants-Malades, 149, rue de Sèvres, 75743-Paris Cedex 15, France. 